\title{
BELAJAR MATEMATIKA MENYENANGKAN MELALUI APLIKASI MODEL MATH MAGIC
}

\author{
Yeni Tri Asmaningtias \\ Dosen Tetap Jurusan PGMI Fakultas Tarbiyah UIN Maliki Malang
}

\begin{abstract}
Math magic school is an institution courses that focus on math. Where students learn in a simple, easy, fast and precise. Math Magic special focus for the basic grade students (elementary to junior high) so that the method used more widely to the game. Before playing a game, Brain Gym is usually done in advance to assist students in learning mathematics, after the Brain Gym method is carried out such a game is a game of dominoes and a calculator paper.

Keywords: Magic School Math, Brain Gym, Domino Card, Paper Calculator.
\end{abstract}

\section{Pendahuluan}

Hudojo (1988:6-8) mengemukakan bahwa belajar matematika akan berhasil bila proses belajarnya baik, yaitu melibatkan intelektual peserta didik secara optimal. Peristiwa belajar yang kita kehendaki bisa tercapai bila faktor-faktor berikut dapat dikelola dengan baik:

1. Peserta didik, misalnya bagaimana kemampuan dan kesiapan peserta didik untuk mengikuti kegiatan belajar matematika, bagaimana sikap dan minat peserta didik terhadap matematika, intelegensinya, kondisi fisiologisnya seperti keadaan segar dan keadaan lelah, kondisi psikologisnya seperti perhatian, pengamatan, ingatan, dll berpengaruh terhadap kegiatan belajar seseorang.

2. Pengajar, misalnya kemampuan dalam menyampaikan dan sekaligus penguasaan materi matematika, kepribadian, pengalaman, dan motivasi mengajar matematika berpengaruh terhadap efektivitas proses belajar.

3. Prasarana dan sarana, misalnya keadaan ruangan dan tempat duduk, buku teks dan alat bantu belajar, dan sumber belajar yang lain seperti majalah tentang pengajaran matematika, laboratorium matematika, dll 
Yeni Tri Asmaningtias_Belajar Matematika Menyenangkan

juga berpengaruh terhadap kelancaran proses belajar.

4. Penilaian, disamping untuk melihat bagaimana hasil belajar, juga melihat bagaimana berlangsungnya interaksi antara pengajar dan peserta didik.

Akan tetapi selama ini yang terjadi di dalam proses pembelajaran matematika banyak yang tidak sesuai dengan teori-teori yang ada, faktorfaktor diatas pun juga tidak dikelola dengan baik. Sebenarnya siswa di sekolah-sekolah bukan tidak mampu dalam proses pembelajaran matematika, akan tetapi mereka sejak awal sudah merasa alergi dan takut sehingga tidak pernah atau malas untuk mempelajari matematika. Hal-hal tersebut disebabkan karena adanya beberapa persepsi yang salah yang sudah mengakar dan menciptakan persepsi negatif terhadap matematika. Salah satunya yang dijabarkan sebagai berikut:

1. Matematika adalah ilmu yang sangat sulit sehingga hanya sedikit orang atau siswa yang mampu memahaminya dengan IQ minimal tertentu. Ini jelas menyesatkan. Meski bukan ilmu yang termudah, matematika sebenarnya merupakan ilmu yang relatif mudah jika dibandingkan dengan ilmu lainnya. Sebagai contoh, amati perbandingan soal untuk siswa kelas 6 sebuah SD swasta berikut ini. Soal pertama, "Sebutkan 3 tarian khas daerah Kalimantan Tengah." Soal kedua, "Sebuah lingkaran dibagi menjadi tiga buah juring dengan perbandingan masing-masing sudut pusatnya adalah $2: 3: 4$, maka hitung besar masing-masing sudut pusat juring-juring tersebut". Ternyata, persentase siswa yang menjawab benar soal kedua lebih besar dibandingkan persentase siswa yang menjawab benar soal pertama. Tanpa ingin mengundang perdebatan, contoh di atas menunjukkan, bahwa matematika bukanlah ilmu yang sangat sukar. Soal matematika terasa sulit bagi siswa-siswa kita karena mereka tidak memahami konsep bilangan dan konsep ukuran secara benar semasa di sekolah dasar. Jika konsep bilangan dan ukuran dikuasai, maka pekerjaan menganalisis dan menghitung menjadi hal yang mudah dan menyenangkan.

2. Matematika adalah ilmu hafalan dari sekian banyak rumus. Persepsi ini membuat siswa malas mempelajari matematika dan akhirnya tidak mengerti apa-apa tentang matematika. Padahal, sejatinya matematika bukanlah ilmu menghafal rumus, karena tanpa memahami konsep, 
Yeni Tri Asmaningtias_Belajar Matematika Menyenangkan

rumus yang sudah dihafal tidak akan bermanfaat. Sebagai contoh, ada soal berikut, "Zaenal merakit sebuah mesin 6 jam lebih lama daripada Indra. Jika bersama-sama mereka dapat merakit sebuah mesin dalam waktu 4 jam, berapa lama waktu yang diperlukan oleh Indra untuk merakit sebuah mesin sendirian ?".

Seorang yang hafal rumus persamaan kuadrat tidak akan mampu menjawab soal tersebut apabila tidak mampu memodelkan soal tersebut ke dalam bentuk persamaan kuadrat. Sesungguhnya, hanya sedikit rumus matematika yang perlu (tapi tidak harus) dihapal, sedangkan sebagian besar rumus lain tidak perlu dihafal, melainkan cukup dimengerti konsepnya. Salah satu contoh, jika siswa mengerti konsep anatomi bentuk irisan kerucut, maka lebih dari 90 persen rumus-rumus irisan kerucut tidak perlu dihafal.

3. Matematika selalu berhubungan dengan kecepatan menghitung. Memang, berhitung adalah bagian tak terpisahkan dari matematika, terutama pada tingkat SD. Tetapi, kemampuan menghitung secara cepat bukanlah hal terpenting dalam matematika. Yang terpenting adalah pemahaman konsep. Melalui pemahaman konsep, kita akan mampu melakukan analisis (penalaran) terhadap permasalahan (soal) untuk kemudian mentransformasikan ke dalam model dan bentuk persamaan matematika. Jika permasalahan (soal) sudah tersaji dalam bentuk persamaan matematika, baru kemampuan menghitung diperlukan. Itu pun bukan sebagai sesuatu yang mutlak, sebab pada saat ini telah banyak beredar alat bantu menghitung seperti kalkulator dan komputer. Jadi, persepsi yang lebih tepat adalah matematika selalu berhubungan dengan pemahaman dan penalaran.

4. Matematika adalah ilmu abstrak dan tidak berhubungan dengan realita. Persepsi ini jelas-jelas salah kaprah, sebab fakta menunjukkan bahwa matematika sangat realistis. Dalam arti, matematika merupakan bentuk analogi dari realita sehari-hari. Contoh paling sederhana adalah solusi dari Leonhard Euler, matematikawan Prancis, terhadap masalah Jembatan Konisberg. Selain itu, hampir di semua sektor, teknologi, ekonomi dan bahkan sosial, matematika berperan secara signifikan. Robot cerdas yang mampu berpikir berisikan program yang disebut sistem pakar (expert system) yang didasarkan kepada konsep Fuzzy Matematika. Hitungan aerodinamis pesawat terbang dan konsep GPS juga dilandaskan kepada konsep model 
Yeni Tri Asmaningtias_Belajar Matematika Menyenangkan

matematika, goneometri, dan kalkulus. Hampir semua teori-teori ekonomi dan perbankan modern diciptakan melalui matematika.

5. Matematika adalah ilmu yang membosankan, kaku, dan tidak rekreatif. Anggapan ini jelas keliru. Meski jawaban (solusi) matematika terasa eksak lantaran solusinya tunggal, tidak berarti matematika kaku dan membosankan. Walau jawaban (solusi) hanya satu (tunggal), cara atau metode menyelesaikan soal matematika sebenarnya boleh bermacam-macam. Sebagai contoh, untuk mencari solusi dari dua buah persamaan, dapat digunakan tiga cara yaitu, metode subtitusi, eliminasi, dan grafik. Contoh lain, untuk membuktikan kebenaran teorema Phytagoras, dapat dipergunakan banyak cara. Bahkan menurut pakar matematika, Bana G. Kartasasmita, hingga saat ini sudah ada 17 cara untuk membuktikan teorema Phytagoras. Solusi matematika yang bersifat tunggal menimbulkan kenyamanan karena tegas dan pasti. Selain tidak membosankan, matematika juga rekreatif dan menyenangkan. Albert Einstein, tokoh fisika terbesar abad ke-20, menyatakan bahwa matematika adalah senjata utama dirinya dalam merumuskan konsep relativitasnya yang sangat terkenal tersebut. Menurut Einstein, dia menyukai matematika ketika pamannya menjelaskan bahwa prosedur kerja matematika mirip dengan cara kerja detektif, sebuah lakon yang sangat disukainya sejak kecil. Memang, cara kerja matematika mirip sebuah games. Mula-mula kita harus mengidentifikasi variabel-variabel atau parameter-parameter yang ada melalui atributnya masing-masing. Setelah itu, laksanakan operasi di antara variabel dan parameter tersebut. Yang paling menyenangkan, dalam melakukan operasi kita dibebaskan melakukan manipulasi (trik) semau kita agar sampai kepada solusi yang diharapkan. Kebebasan melakukan manipulasi dalam operasi matematika inilah yang menantang dan mengundang keasyikan tersendiri, bak sedang dalam permainan atau petualangan. Karena itu, tidak mengherankan jika terkadang kita menjumpai siswa yang asyik menyendiri dengan soal-soal matematikanya. Selain itu, secara intrinsik matematika juga memiliki angka berupa bilangan bulat yang mengandung misteri yang sangat mengasyikkan. Misalnya Anda melakukan operasi perkalian maupun pertambahan terhadap dua bilangan tertentu, maka terkadang akan muncul bilangan yang memiliki bentuk simetri tertentu. Contoh lain, Anda dapat 
Yeni Tri Asmaningtias_Belajar Matematika Menyenangkan

menunjukkan kemahiran menebak dengan tepat angka tertentu yang telah mengalami beberapa operasi. Bagi yang belum memahami matematika, kemampuan Anda menebak angka dianggap sihir, padahal itu merupakan operasi.

\section{B. Math Magic School}

(http://math magicschool.blogspot.com/2008/12/apa-itu-math-magicschool.html)

Math magic school merupakan lembaga kursus yang memfokuskan pada mata pelajaran matematika. Dimana para siswa belajar dengan cara yang sederhana, mudah, cepat, dan tepat. Selain itu Math Magic lebih mengedepankan para siswanya untuk menggali dan mengetahui kecerdasan majemuk yang dimilikinya.

Pada Math Magic metode belajar disesuaikan dengan cara gaya belajar tiap siswa. Hal ini dilakukan untuk membantu pengajar agar kegiatan belajar sangat efektif. Untuk mengetahui gaya belajar para siswa Math Magic dilakukan pengisian test gaya belajar bagi orangtua dan siswa itu sendiri. hasil dari test akan dicocokkan dengan gaya belajar siswa d kelas. Math Magic membagi tingkatan-tingkatan belajar seperti berikut:

Level DASAR :

- $\quad$ Junior $=>$ Siswa kelas Tk b

- Level $1 \mathrm{~A}=>$ Siswa kelas 1 \& $2 \mathrm{SD}$

- Level 1 B => Siswa kelas 3 \& 4 SD

- Level $1 \mathrm{C}=>$ Siswa kelas 5 \& 6 SD

C. BRAIN GYM

Tujuan :

- Mempersiapkan otak anak untuk belajar

- Melatih anak untuk lebih fokus dan konsentrasi

- Melatih daya ingat

- Melatih sistem motorik halus pada anak 
Yeni Tri Asmaningtias_Belajar Matematika Menyenangkan

Brain gym adalah program pelatihan yang dikembangkan oleh prof. paul E.Dennison,PhD dan Gail E. Dennison sejak tahun 1970. Awalnya program ini dirancang untuk mengatasi gangguan belajar pada anak-anak dan orang dewasa. Dasar pemikirannya ,belajar adalah kegiatan alami dan menyenangkan yang dilakukan sepanjang hidup. Kesulitan belajar biasanya berasal dari ketidakmampuan mengatasi stres dan keraguan dalam menghadapi tugas baru. Setiap orang tua tentu menginginkan anak yang berdaya pikir kuat. Untuk itu tak jarang orang tua berlomba-lomba menemukan metode atau cara baku untuk meningkatkan kualitas intelegensia anak. Memang, tidak ada satu metode pun yang dapat menjamin seratus persen anak menjadi lebih cerdas. Disamping memberikan nutrisi yang tepat, langkah paling jitu adalah memberikan stimulasi yang optimal dan tepat, salah satunya dengan mengajak anak bergerak. Pergerakan tubuh tak hanya mendorong anak aktif bereksplorasi atau bermanfaat bagi fisiknya, melainkan juga menstimulasi saraf otak anak.

Dr.Paul E Dennison, seorang pendidik asal Amerika Serikat, mengembangkan suatu pendekatan yang dinamakan Educational Kinesiology (Edu-K) atau Kinesiologi pendidikan yang bertujuan untuk melatih fungsi otak yang berhubungan dengan tahap Kinesiology (Edu-K) atau Kinesiologi pendidikan yang bertujuan untuk melatih fungsi otak yang berhubungan dengan tahap perkembangan tertentu atau meningkatkan kemampuan belajar anak.

Education berasal dari kata latin educare yang berarti menarik keluar. Kiniseology dikutip dari bahasa yunani berarti gerakan dan merupakan pelajaran gerakan tubuh manusia. Edu-K adalah suatu sistem yang memberdayakan semua orang yang belajar, tanpa batas umur dengan menggunakan aktivitas gerakan-gerakan untuk menarik keluar seluruh potensi seseorang.

Dengan latar belakang tersebut, maka Paul Dennison menciptakan brain gym, yaitu pembaharuan pola bergerak untuk dapat membantu mengoptimalkan kemampuan belajar anak dengan meningkatkan pengaliran energi (vitalitas) ke otak. Kegiatan brain gym sendiri bersifat aman, sederhana dan alamiah.

Kegiatan brain gym bertujuan untuk mengintregasikan setiap bagian otak untuk membuka bagian otak yang sebelumnya tertutup atau terhambat. 
Yeni Tri Asmaningtias_Belajar Matematika Menyenangkan

Dapat dibayangkan bagaimana jadinya kalau masing-masing belahan otak berkembang sendiri-sendiri," tentu nya tidak akan terjadi keselarasan. Ketidakselarasan kerja otak juga akan mengakibatkan anak mengalami berbagai hambatan, terutama pada proses belajarnya kelak di sekolah.

Henry Remanly, instruktur brain gym yang mendapat lisensi dari International Kinesiology College, California, AS, mengatakan selama ini hanya timbul persepsi bahwa otaklah yang mengendalikan semua bagian tubuh. Namun, justru dengan bergerak juga memberikan efek stimulan terhadap dengan bergerak juga memberikan efek stimulan terhadap pertumbuhan saraf. Beberapa penelitian pun membuktikan bahwa dengan melakukan olahraga rutin akan menstimulasi perkembangan otak.

Metode brain gym yang merupakan sebuah metode melalui 26 gerakan dasar untuk menstimulasi dan menyeimbangkan seluruh bagian otak, otak kiri-kanan, atas-bawah dan depan-belakang. Gerakan-gerakan telah dikelompokkan sesuai dengan area otak. "Metode ini telah dikembangkan selama lebih dari 25 tahun yang menitikberatkan pada pembelajaran. Banyak anak dengan gangguan belajar dan disleksia dapat diatasi," kata Henry.

Henry menyebutkan, metode brain gym tak hanya bermanfaat bagi anak berkebutuhan khusus atau kesulitan belajar. Gerakan brain gym bisa dicobakan pada setiap anak yang membutuhkan optimilasasi kerja otak. Terutama usia dini yang tengah belajar mengenal lingkungan melalui inderanya dan apa yang ia pelajari akan menstimulasi peningkatan jumlah saraf. "Gerakan brain gym bisa diterapkan pada anak segala usia, bahkan sejak bayi. Namun, gerakan tetap harus disesuaikan dengan perkembangan motorik anak pada usia tertentu," paparnya.

Lely Tobing, anggota asosiasi brain gym Indonesia mengatakan gerakan brain gym dapat dipraktekkan anak sejak dini. Karena secara teknisnya, gerakan tersebut dapat mengembangkan 3 dimensi otak, yaitu pertama, dimensi lateritas untuk mengintegrasikan otak belahan kiri dan kanan. Bila seseorang anak bermasalah pada dimensi lateritas, maka akan tampak koordinasi tubuh kiri-kanan kurang bagus dan akan tampak pada akitivitas hariannya, seperti memakai baju sendiri, lempar tangkap bola, menggambar, komunikasi, bernafas, dan lain-lain.

Kedua, dimensi pemfokusan untuk otak bagian belakang dan bagian depan. Dimensi fokus untuk mengkoordinasi si bagian tubuh muka 
Yeni Tri Asmaningtias_Belajar Matematika Menyenangkan

belakang, batang otak atau brainstem dan bagian otak depan (frontal lobes). Untuk anak yang dimensi fokus tidak seimbang maka akan tampak koordinasi depan belakang yang bermasalah seperti: gampang capek, otototot kaku terutama bagian belakang, mudah jengkel, fokus kurang, atau tidak mampu mengendalikan diri, kapan harus berhenti dan kapan harus maju dalam berbagai hal.

Pergerakan tubuh sebagai stimultan otak yang merupakan pintu sebuah proses pembelajaran anak

Ketiga dimensi pemusatan yang dapat menyeimbangkan posisi depan dan belakang (sistem limbis/midbrain) serta otak besar (cerebal cortex). Untuk anak yang dimensi pemusatannya bermasalah, maka akan tampak pada koordinasi tubuh atas bawah tidak terkoordinasi seperti: melompat, keseimbangan, jongkok, berdiri, gampang jatuh tersandung, takut ketinggian, dari sisi emosi yang tak terkontrol, dan agresif atau justru pasif. Dengan keseimbangan ini, diharapkan membantu kebutuhan tumbuh kembang kelak, sebab itu perlu stimulasi sejak dini.

Dengan melakukan rutinitas gerakan brain gym, ujar Lely, niscaya anak akan mendapatkan manfaat. Antara lain, meningkatnya konsentrasi, stamina, rasa percaya diri, membebaskan stress, meningkatkan konsentrasi, kemampuan mengontrol emosi, mengembangkan kemampuan menyanyi, musik, dan logika. Selain itu, dapat membantu anak mengoptimalkan persepsi informasi yang diterima melalui indera dan meningkatkan kinerja semua bagian otak agar terintegrasi. "Terkadang oleh suatu hal perkembangan saraf anak akan terhambat, hal ini akan mempengaruhi respon tubuh. Brain gym dapat membuka jalan keluar di bagian otak yang terhambat agar dapat berfungsi maksimal," ujar Henry.

\section{Gerakan Brain Gym sesuai usia}

Lely menerangkan, brain gym adalah gerakan repatterning yang memerlukan pengulangan dan konsentrasi. Sebaiknya lakukan 3 kali dalam sehari yang disesuaikan dengan rutinitas anak, misalnya pada saat pagi hari, sesudah mandi, siang hari sesudah istirahat siang dan sore hari. Selain itu, di setiap gerakan juga terdapat pengulangan gerakan. 
Yeni Tri Asmaningtias_Belajar Matematika Menyenangkan

Namun, jangan jadikan kegiatan ini menimbulkan stres pada anak. Sebaiknya gerakan dilakukan dalam keadaan rileks. Hindari memaksa anak yang berakibat kehilangan minat.

Langkah pembukaan dalam brain gym meliputi PACE (Positive, Active, Clear, dan Energetic) positif, aktif, tanggap, dan energik. Proses PACE diharapkan untuk menghantar ke dalam suatu keadaan yang nyaman untuk belajar. Proses PACE terdiri dari 4 aktivitas sederhana yaitu air (untuk usia di bawah 2 tahun, air diganti dengan ASI), saklar otak, homolateral/gerakan silang dan kait rileks. Khusus untuk gerakan kait rileks, yaitu menyatukan ujung-ujung jari selama satu menit dan berdiam diri sejenak, balita akan memerlukan bantuan.

Lely menganjurkan agar sebisa mungkin brain gym dilakukan dalam konteks bermain. Orang tua juga harus merasa nyaman, tenang, dan aman ketika memandu anak. Sehingga gerakan dapat mudah diikuti anak. Mulailah dengan langkah-langkah sederhana. Ajak anak mempelajari gerakan per gerakan dalam jangka waktu tertentu. Misalnya pengulangan satu gerakan di minggu pertama, lalu gerakan berikutnya di minggu ke-2, dan sebagainya.

\section{Usia 0-6 Bulan}

- Saklar anak

Pijat jaringan lunak di bawah tulang selangka di kiri dan kanan tulang dada, sementara tangan yang lain memegang pusar. Fungsi: mengirim pesan dari bagian otak kanan ke sisi kiri tubuh dan sebaliknya. Serta meningkatkan penerimaan oksigen.

- Tombol Bumi

Memijit titik di bawah bibir dan tangan lain di tulang kemaluan. Fungsi: mengaktifkan energi di otak tengah, menyeimbangkan emosi, mengaktifkan kemampuan melihat atas dan bawah.

- Tombol Angkasa

Memijit titik di atas bibir dan tangan lain memegang tulang ekor. Fungsi: mengaktifkan energi ke otak, menyeimbangkan kemampuan melihat jauh dekat, menyeimbangkan emosi. 


\section{Usia 6 Bulan-1 Tahun}

- Gerakan merenggangkan otot. Buka tangan anak ke kanan dan ke kiri. Fungsi: membantu mengaktifkan dan memperkuat perkembangan otot.

- Gerakan homolateral

Gerakan tubuh satu sisi. Pada usia bayi umumnya menggerakan badan dengan menggunakan 1 sisi tubuhnya. Misalnya, merayap untuk menggapai suatu benda, tangan berusaha menjangkau dan kaki di bagian yang sama mengikutinya. Lalu, pada saat anak berusaha untuk membalikkan tubuh, maka dia akan bertumpu di satu sisi saja.

Fungsi: untuk menekankan perkembangan otak di bagian tertentu

- Gerakan menyilang

Gerakan anggota badan secara menyilang. Tangan kanan digerakkan bersamaan dengan kaki kiri. Lalu tangan kiri digerakkan bersamaan dengan kaki kanan.

Fungsi: untuk mengaktifkan koordinasi antara bagian otak kiri dan kanan.

\section{Usia 1-2 Tahun}

- Gerakan menyilang.

- Tombol imbang(balance button).

Sentuh belakang telinga anak sambil tangan yang lain menyentuh pusar.

Fungsi: menyeimbangkan ketiga dimensi otak, kiri-kanan, atasbawah, dan belakang-depan.

\section{Usia 2-3 Tahun}

Lakukan semua gerakkan di atas pada anak, minta anak mengikuti gerakan yang diajarkan.

- Pasang telinga 
Yeni Tri Asmaningtias_Belajar Matematika Menyenangkan

Dengan menggunakan ibu jari dan jari telunjuk untuk menarik kedua telinga anak dengan lembut keluar dan melepas gulungannya dimulai dari puncak telinga dipijat lembut sepanjang lengkungannya, berakhir di bagian bawah (3 titik atas tengah bawah).Ulangi 3 kali atau lebih.

Fungsi: membedakan persepsi memori auditori, mendengarkan suaranya sendiri saat berbicara, daya ingat jangka pendek, bicara dalam hati, dan keterampilan berpikir, mendengarkan dengan kedua telinga.

- 8 tidur

Bantu anak menggerakkan tangan dari mulai titik, tengah ke arah kiri atas, melingkar ke kiri bawah naik ke titik tengah lagi dan terus ke kanan atas, berputar ke kanan bawah, dan kembali ke titik tengah (seperti menggambar angka 8 tidur).

Fungsi: mengaktifkan mata kanan dan kiri serta mengintregasikan bidang kanan dan kiri.

Sebagai variasi, kata Lely, orang tua juga bisa mengkombinasikan gerakan brain gym dengan penggunaan alat bantu. Untuk bayi, orang tua bisa menggunakan alat bantu untuk menarik perhatian anak seperti balon, mainan berbunyi, tongkat berpita, stiker bergambar untuk ditempelkan di tangan orang tua. Alat ini membantu anak untuk membuat gerakan silang serta melatih koordinasi mata anak. Misalnya, dengan menggerakan mainan berbunyi kekiri kanan,atau gunakan balon menarik perhatiannya saat anak merangkak. Sedangkan untuk anak yang sudah lebih besar, gunakan kartu bergambar untuk menunujukkan langkah-langkah gerakkan brain gym.

Tips brain gym menyenangkan bagi Si Kecil

1. Brain gym dapat digabung atau dihantarkan dengan musik yang menyenangkan, berirama tenang atau disukai anak ,sehingga membuat anak lebih rileks.

2. Membuat situasi ruangan yang menyenangkan dan nyaman untuk anak, misalnya meletakkan bayi di atas matras.

3. Pakaikan anak baju yang nyaman untuk bergerak. 
4. Karena tubuh kita $70 \%$ lebih mengandung air, maka memberikan air putih sebagai langkah pendahuluan sangat disarankan.

5. Orang tua sendiri juga harus dalam keadaan rileks dan menyenangkan saat memberikan pelatihan kepada anak.

(http://www.ibudanbalita.com/pojokcerdas/tingkatkan-kualitaskecerdasan-anak-dengan-brain-gym)
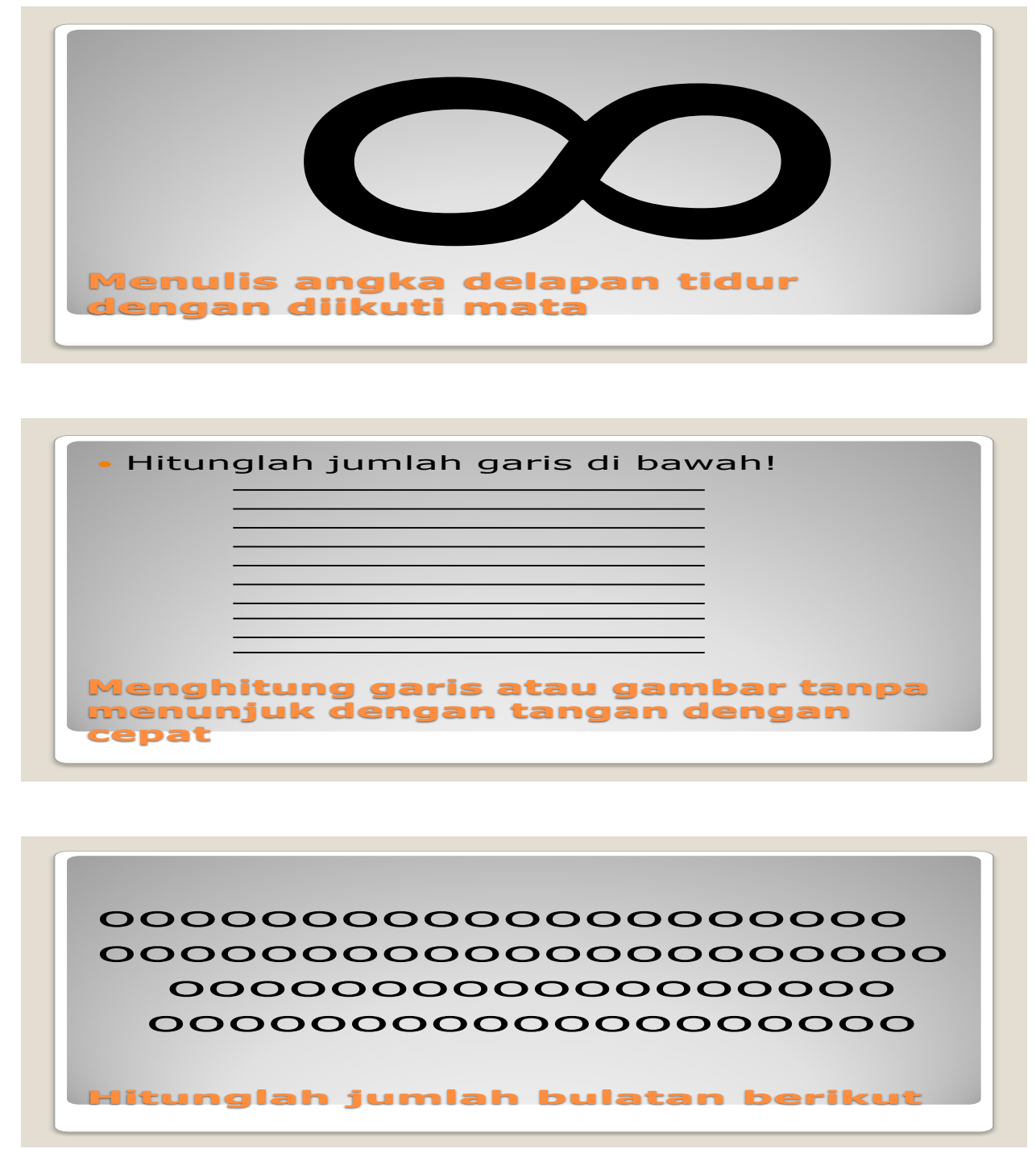

92 Madrasah, Vol. 4 No. 1 Juli-Desember 2011 


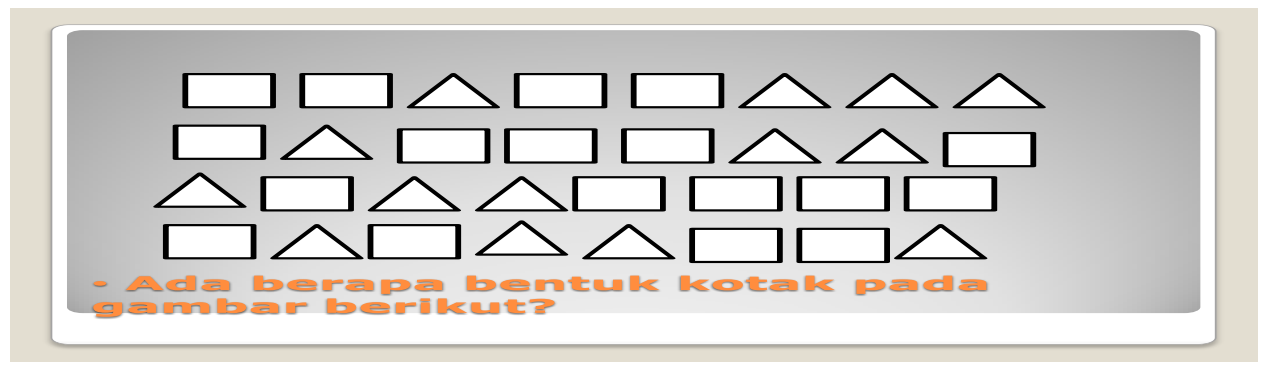

D. 10 hukum dasar otak

\section{Hukum Dasar Otak}

"Otak merupakan alam semesta mini". Ini bukan merupakan pernyataan simbolis seperti yang ditemukan pada kalimat analogi, "wajahnya bagaikan bulan purnama". Pernyataan itu benar-benar empiris dan memang begitu adanya. Otak manusia merupakan organ tubuh yang paling kompleks yang dimiliki oleh manusia. Selama puluhan tahun para ahli mengkaji tentang rahasia dan sistem kerja otak, namun belum juga terselesaikan hingga saat ini. Suatu keniscayaan bahwa penilitian akhir para ahli berujung pada hal-hal ghaib. Hal ini sekaligus membuktikan bahwa manusia dengan pimikirannya yang lahir dari otak merupakan ciptaan Tuhan.

Struktur dan sistem kerja otak secara umum merupakan representasi dari alam semesta yang juga merupakan ciptaan Tuhan. Di dalam otak terdapat berbagai persamaan geografis dengan alam semesta, sebagai berikut:

\begin{tabular}{|l|l|}
\hline Otak Manusia & Alam Semesta \\
\hline Sel-sel saraf & Pohon-pohon \\
\hline Pembuluh Darah & Sungai, gua, terowongan \\
\hline Kulit otak & Hamparan tanah dan hutan \\
\hline Sulcus & Lembah \\
\hline
\end{tabular}

93 Madrasah, Vol. 4 No. 1 Juli-Desember 2011 
Yeni Tri Asmaningtias_Belajar Matematika Menyenangkan

\begin{tabular}{|l|l|}
\hline Gyrus & Bukit \\
\hline
\end{tabular}

Persamaan proses-proses yang berlangsung dalam otak antara lain tampak dari hukum-hukum dan aturan dasar yang berlangsung dalam otak manusia yang disebut hukum-hukum otak. Hukum-hukum otak ini amat berguna bagi kita dipandang dari berbagai disiplin ilmu. Berbagai hukum tersebut dapat kita gunakan sebagai dasar untuk mengembangkan kecerdasan.

Persamaan proses-proses di otak antara lain tampak dari hukum-hukum atau aturan-aturan dasar yang berlangsung dalam otak manusia. Jika alam semesta memiliki hukum-hukum alam, maka di otak pun terdapat hukumhukum otak.

\section{Hukum pertama: Otak menyimpan informasi}

Sel-sel saraf adalah gudang penyimpanan. Namun, tidak seperti gudang penyimpanan beras yang tidak bertambah besar, sel-sel saraf otak menyimpan informasi melalui pertautan satu dengan yang lainnya. Semakin banyak pertautan, semakin kuat dan lama informasi itu disimpan. Logikanya, makin tua umur seorang manusia, makin banyak sel saraf dikepalanya.

Tidak seperti sel-sel dalam jantung yang tidak merespons rangsangan belajar, sel-sel otak justru bertambah dengan belajar.

Jika ada sel-sel saraf yang hilang, misalnya karena umur yang makin tua, pasti ada informasi dan kemampuan yang hilang. Ini bisa jangka panjang atau jangka pendek.

Kehilangan sel saraf, yang artinya kehilangan informasi dapat dicegah dengan pengulangan-pengulangan informasi maupun perilaku.

\section{Hukum kedua: Otak memiliki komponen untuk menciptakan} kebiasaan-kebiasaan dalam berpikir dan berperilaku

Ketika seseorang belajar untuk pertama kalinya, maka informasi itu dikemas dan ditata dalam wilayah sadar dikulit otak(kulit otak adalah wilayah indrawi dan rasional otak manusia). Jika kegiatan sadar itu berlangsung terus-menerus(pengulangan jangka lama), maka penataan kegiatan itu akan dialihkan ke wilayah tak sadar di ganglia basalis. Ketika 
Yeni Tri Asmaningtias_Belajar Matematika Menyenangkan

memasuki wilayah tak sadar, maka kegiatan itu akan berlangsung secara otomatis.

Belajar berulang-ulang tidak saja memperkuat tautan sel saraf atau memperbanyak jumlahnya(hukum pertama otak), tetapi juga menciptakan jalur saraf khusus ke wilayah tak sadar. Otak manusia mempunyai keunikan dan kelebihan khusus dalam membuka jalan baru ke wilayah tak sadar. Dan lebih hebat lagi, otak memiliki akses tak terbatas ke wilayah tak sadar itu. Orang yang tak biasa menulis dengan tangan kiri akan kesulitan melakukannya. Mengapa? karena belum tercipta jaur khusus ke wilayah tak sadarnya. Jika ia melakukanya berulang-ulang, jalur itu akan tercipta dan ia akan sangat terampil menulis dengan menggunakan tangan kirinya.

Banyak yang berpendapat bahwa menghafal bahasa inggris dengan kamus bergambar lebih mudah daripada kamus biasa. Mengapa? karena kamus pertama menulis kata dengan gambar.

Layaknya pelajaran anatomi manusia lebih dilakukan jika ada gambar daripada hanya tulisan dan kata-kata biasa.

Gambar, grafik, tabel, skema, yang dikemas dengan warna-warna mencolok akan memudahkan otak untuk menyimpannya. Jika informasi tersebut dikemas hanya dalam bentuk kata, ia hanya disimpan di otak kiri yang ahli dibidang penyimpanan kata.

Otak kiri adalah gudangnya kata. 90\% kegiatan berbahasa terjadi pada otak kiri. Jika informasi itu dalam bentuk gambar yang penuh warna, maka penyimpanannya dilakukan di otak kanan. Informasi dalam paduan kata dan gambar akan semakin cepat diserap dan tersimpan. Potensi penyimpanan seperti ini besar sekali, namun kebanyakan manusia hanya memakai satu belahan otaknya saja. Warna yang beraneka ragam juga dapat menyulut emosi tertentu.

Otak akan memerintahkan pelepasan zat tertentu, misalnya adrenalin, untuk membuat denyut jantung bertambah dan rassa cemas meningkat, hanya karena seseorang bermimpi dikerjar anjing. Demikian halnya ketika seseorang datang di suatu tempat yang mengingatkannya pada sebuaah kejadian traumatis.

Yang penting bagi otak bukanlah kejadian yang sedang berlangsung, tetapi bagaimana respons otak atas kejadian itu. Inilah yang memungkinkan kejadian-kejadian masa lalu direspons sebagai kejadian masa kini. Karena 
Yeni Tri Asmaningtias_Belajar Matematika Menyenangkan

itu, respons pertama menentukan bagaimana kejadian itu harus disimpan dan bagaimana reaksi otak ketika melihat kejadian itu.

Passive Thinking-- yakni berpikir tanpa melakukan kegiatan yang sesugguhnya--dapat melatih respons otak secara cepat dan tepat.

Prinsip kerja dua belahan itu(otak kanan dan kiri) seperti halnya kedua belah mata.

Sebuah objek--katakanlah sebuah pohon--di depan mata memang ditangkap dengan satu mata saja. Namun, tangkapan dua buah mata akan jauh lebih baik. Demikian halnya "tangkapan" otak. Karena itu yang sempurna dibandingkan satu belahan saja.

Otak kanan dapat dipakai untuk menguatkan diri secara keseluruhan.

Diri yang dimaksud adalah keseluruhan aspek pikiran, perasaan, dan tindakan manusia.

Dengan imajinasi kreatif, yang merupakan keahlian khusus otak kanan, banyak hal yang dapat dilakukan. Jika otak kiri hanya dapat membuat rumah di alam nyata, maka otak kanan dapat membuat rumah yang jauh lebih baik atau lebih hebat di alam imajinasi.

Namun, berbeda dengan angan-angan kosong, imajinasi kreatif dapat memotivasi diri untuk mencapai apa yang diinginkan.

Tidak seperti lazimnya--melihat dahulu baru mempercayainya(seeing is believing)--mekanisme kerja otak kanan sebaliknya: mempercayai dahulu baru melihat(believing is seeing).

Hukum keenam: Konsep dan informasi dalam otak disusun dalam bentuk pola-pola. Otak dapat menerima sekaligus menolak pols-pola itu. Otak terikat sekaligus tidak terikat dengan pola.

Gambaran suatu benda akan disimpan pada tempat yang berbeda-beda di otak. Gambaran pisang akan disimpang pada tempat yang berbeda-beda. Bentuknya disimpan di lobus parietal, warna di lobus temporal, dan baunya di lobus frontal. Pemahaman terhadap sebuah informasi adalah hasil kerja sama semua bagian otak.

Akibat dari klasifikasi tersebut, otak akan berpikir menurut pola-pola tertentu. Setiap informasi masuk akan "dibaca" menurut pola yang disimpan. Walaupun memerlukan waktu, otak dapat "membaca" pola yang 
Yeni Tri Asmaningtias_Belajar Matematika Menyenangkan

berbeda dari data yang disimpannya. Kemampuan otak ini dapat direkayasa untuk memunculkan kreativitas.

Hukum ketujuh: Alat-alat dan reseptor saraf menghubungkan otak dengan dunia luar. Latihan indra dan fisik dapat memperkuat otak. Dunia luar adalah sumber informasi yang tak terbilang banyaknya. Informasi itu tidak dapat diterima secara langsung oleh otak. Informasi hanya dapat diterima oleh otak setelah kontak dengan alat-alat indra dan reseptor saraf yang ada di permukaan tubuh. Pengenalan seseorang terhadap alat indra yang dominan akan membantu otak menyimpan informasi secara baik. Misalnya, jika berkenalan dengan seseorang, akan jauh lebih kuat bagi otak untuk menyimpan informasi kenalan baru tersebut bila bukan hanya namanya yang diingat. Warna baju, bau badan, dan parfumnya, tatapan matanya, genggaman tangannya, suaranya, akan menguatkan ingatan dan penyimpanan di otak.

Dengan kata lain, ketika belajar, informasi itu harus dilihat didengar, disentuh dicium, bahkan dirasai. Ingatan itu akan lebih kuat bila nuansa emosional dilibatkan. "Kesan pertama menentukan" kira-kira begitulah nuansa emosi itu. Rasa suka, benci, kagum, senang adalah nuansa-nuansa emosi yang mendukung daya ingat.

Hukum kedelapan: Otak tidak pernah istirahat. Ketika "otak rasional" kelelahan dan tidak dapat menuntaskan sebuah pekerjaan, maka "otak intuitif" akan melanjutkannya.

Otak kanan dan otak kiri melakukan kegiatan berbeda, tetapi terpadu. Umumnya ketika berpikir, seseorang hanya menggunakan pikiran-pikiran rasionalnya. Ciri pikiran ini adalah indrawi, logis, memusat, dan tidak melahirkan hal-hal atau cara-cara baru sehingga cenderung kaku dan berpola.

Seringkali cara berpikir rasional tidak dapat menyelesaikan masalah. Apalagi jika masalah itu tidak memiliki dasar-dasar indrawi atau logis. Karena itu, pikiran intuitif harus dapat diaktifkan. Jenis pikira ini-meskipun bertumpu pada pikiran rasional--memiliki mekanismenya sendiri.

Pikiran ini sering disebut pikiran tidak logis, diluar kebiasaan, dan menyebar. Jika pikiran ini mampu diaktifkan, banyak hal yang dapat dipecahkan. Hanya saja, pengaktifan pikiran intuitif harus didahului dengan pengaktifan besar-besaran atau sekuat-kuatnya pikiran rasional. 
Yeni Tri Asmaningtias_Belajar Matematika Menyenangkan

Pikiran rasional harus bekerja all out hingga mencapai taraf kebuntuan berpikir.

Mengarahkan semua kekuatan pikiran logis dapat memunculkan pikiran intuitif.

Hukum kesembilan: Otak dan Hati berusaha dekat. Otak yang diasah secara terus-menerus dapat membawa pemiliknya ke jalan kebajikan dan kebijaksanaan, serta ketenangan jiwa.

Ini ada hubungannya dengan agama. Karena dengan mengoptimalisasikan spiritualismenya seseorang dapat hidup secara lebih baik dan eksistensinya akan lebih terwujud.

Optimalisasi otak spiritual dapat membuat seseorang cerdas secara utuh.

Paling tidak, terdapat tiga komponen hidup yang lahir dari optimalisasi itu:

1. Kejernihan berpikir rasional

2. Kecakapan emosi

$3 . \quad$ Ketenangan hidup

Dalam hal optimalisasi ini, jenis institusi agama yang dianut bukanlah hal terpenting. Yang paling penting adalah nilai-nilai yang dikandung oleh sebuah institusi agama itu.

Ketenangan hidup merupakan hasil akhir yang paling tinggi nilainya dari otak spiritual. Sebab, kecerdasan rasional dan kecakapan emosi tidak ada apa-apanya bila seseorang tidak memiliki ketenangan hidup. Melatih otak terus-menerus dan membiasakannya untuk merenung akan membuat hati tenang dan bercahaya. Kecemasan dan ketegangan dapat dihilangkan dengan membiarkan otak "menemukan" dimensi spiritual yang dimilikinya.

Hukum kesepuluh: Kekuatan otak turut ditentukan oleh makanan fisik yang diterima otak.

Otak dipelihara oleh makanan yang diterimanya.

Otak juga dipelihara oleh asupan darah yang cukup. Asupan darah yang berlangsung baik, dengan makanan yang tersedia secara baik, dapat memelihara otak untuk berfungsi secara baik.

Sebaliknya, asupan darah yang tidak cukup, misalany oleh hambatan pada pembuluh darah atau pecahnya pembuluh darah, dapat menghilangkan kekuatan otak. Aliran darah yang terhenti sedetik saja dapat menyebabkan iskemia (gangguan sepintas) maupun infark (mati)-nya otak. Jika otak sudah mati, pasti terjadi gangguan fungsi pada daerah yang bersangkutan. Makanan yang mengganggu aliran darah dapat mengganggu otak. Bila 
Yeni Tri Asmaningtias_Belajar Matematika Menyenangkan

terdapat kerak-kerak, misalnya kerak kolesterol atau lemak pada pembuluh darah, maka aliran darah tidak akan berjalan sebagaimana mestinya. Gula yang dibutuhka otak tidak akan cukup. Padahal gula merupakan sumber utama bahan bakar otak.

E. Bermain kartu domino

Tujuan :

Membantu anak - anak dalam menghafal operasi perkalian, pembagian, penjumlahan dan pengurangan dasar

- Latihan kecepatan dan konsentrasi

- Melatih sosialisasi anak dengan teman

\section{Cara kerja}

- Siapkan 1 set kartu domino

- Bentuk sebuah kelompok melingkar dengan anggota 3 - 6 orang

- Kocok kartu domino

- Bagikan domino pada masing - masing anak sebanyak 5 - 8 kartu (tergantung kebutuhan)

- Kartu yang paling cepat habis dialah pemenang

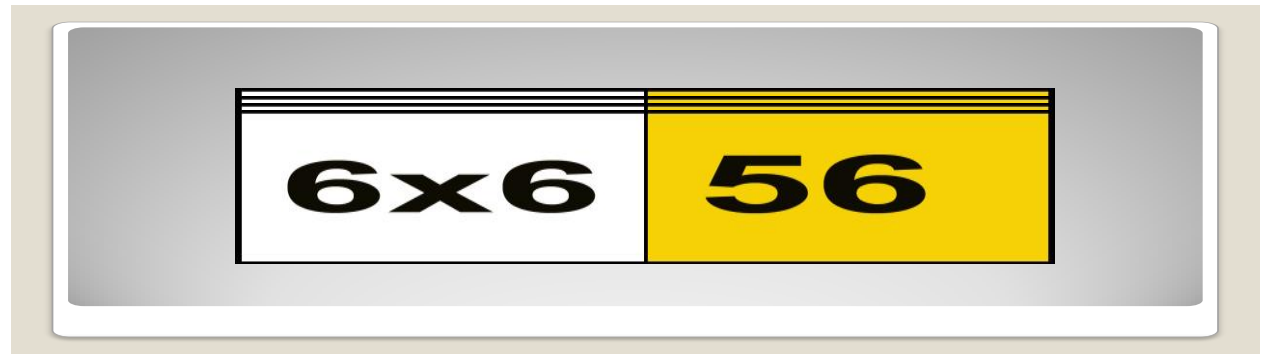

Perkalian silang

- Membantu anak - anak mempermudah menghitung perkalian 
Yeni Tri Asmaningtias_Belajar Matematika Menyenangkan

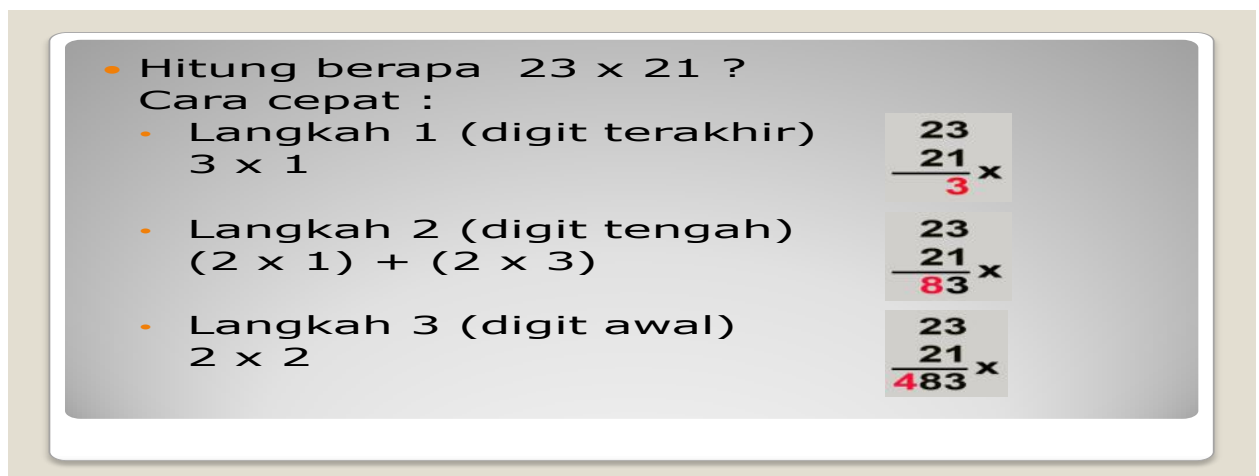

Kalkulator kertas

Tujuan :

- Membantu anak - anak mempermudah menghitung perkalian
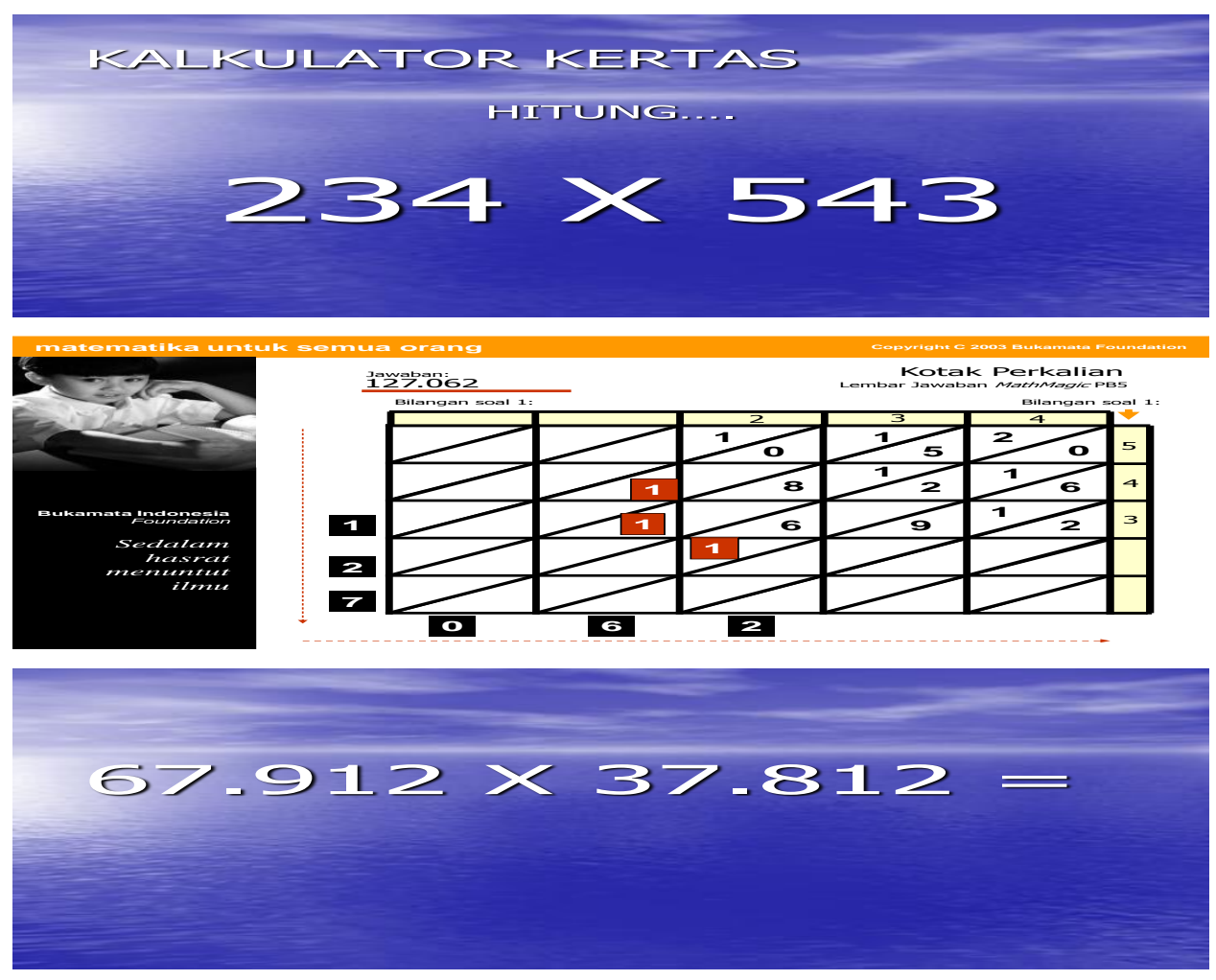

100 Madrasah, Vol. 4 No. 1 Juli-Desember 2011 

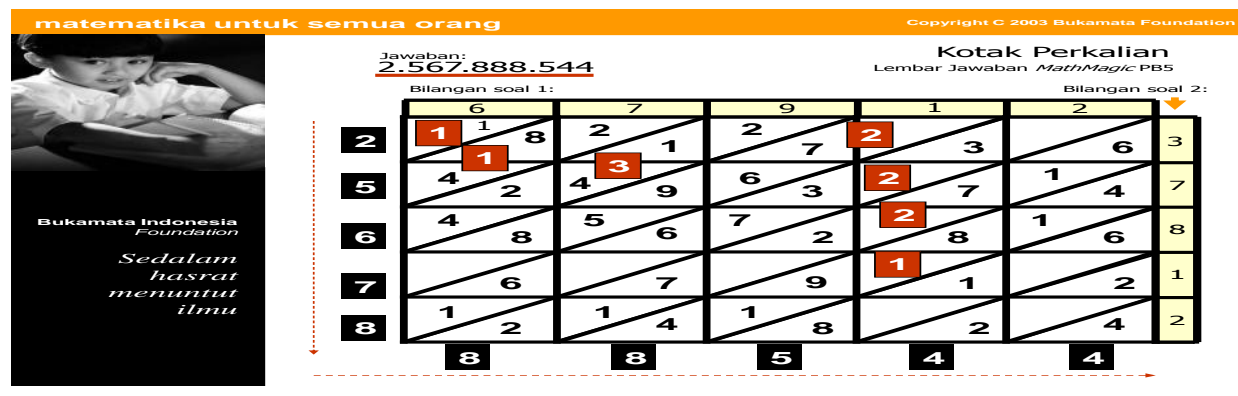

F. Kesimpulan

Math magic school merupakan lembaga kursus yang memfokuskan pada mata pelajaran matematika. Dimana para siswa belajar dengan cara yang sederhana, mudah, cepat, dan tepat. Selain itu Math Magic lebih mengedepankan para siswanya untuk menggali dan mengetahui kecerdasan majemuk yang dimilikinya.

Dengan memfokuskan pada siswa kelas dasar (SD sampai SMP) maka metode yang dipakai lebih banyak ke permainan. Sebelum melakukan permainan, biasanya dilakukan brain gym terlebih dahulu untuk membantu siswa dalam mempelajari matematika, setelah brain gym maka dilakukan metode permainan diantaranya adalah permainan kartu domino dan kalkulator kertas.

Karena masing-masing siswa memiliki kemampuan dan gaya belajar yang berbeda, Math Magic juga melakukan test gaya belajar bagi orangtua dan siswa yang bertujuan untuk membantu pengajar agar kegiatan belajar sangat efektif dan menyesuaikan cara belajar masingmasing siswa. Biasanya siswa harus menyesuaikan gaya belajar lembaga pendidikan yang diikutinya, tetapi di Math Magic School lembaga pendidikan yang menyesuaikan gaya belajar siswa, dan ini yang membuat UNIK Math Magic.

\section{Daftar Pustaka}

(Http:/ / masterhipnoterapi.blogspot.com/2010/10/10-hukum-dasarotak-part-1.html) diunduh pada hari senin tanggal 4 April 2011

(Http:/ / mathmagicschool.blogspot.com/2008/12/apa-itu-mathmagic-school.html) diunduh pada hari senin tanggal 4 April 2011 
Yeni Tri Asmaningtias_Belajar Matematika Menyenangkan

(ttp://www.ibudanbalita.com/pojokcerdas/tingkatkan-kualitaskecerdasan-anak-dengan-brain-gym) diunduh pada hari senin tanggal 4 April 2011

Hudojo, Herman. 1988. Mengajar Belajar Matematika. Depdikbud. Jakarta.

Sutomo, Heru. 2010. Math Magic School, Belajar Matematika Menyenangkan. Makalah disampaikan dalam Workshop Pembelajaran Matematika di UIN Maliki Malang 